heredity and variation (Om Arvelighed og Variabilitet, 1896). The subtle distinctions between the first speculative expressions of an idea and its subsequent formulation on the basis of experiment and detailed observation are captured in this account. Thus Correns' 1902 mechanism for crossingover, Professor Dunn points out, does not involve the exchange of blocks of units but of one or more pairs at random. This book is provided with a 4-page Glossary and an invaluable I 7-page Bibliography.

R. G. Olby.

\title{
FUNGAL MATING-TYPES
}

INCOMPATIBILITY IN FUNGI. A Symposium held at the 10th International Congress of Botany at Edinburgh, August 1964. Edited by Karl Esser and John R. Raper. Springer-Verlag, Berlin, 1965. Pp. viii+124, 8vo. Stiff paper bound. DM. 24.

This publication consists of the contributions to a symposium on Incompatibility in Fungi held at the roth International Botanical Congress in Edinburgh in August 1964. The speakers included many of the leading workers in this field. The editors have standardised the terminology of the various contributions, with the exception of Professor J. H. Burnett's paper on the natural history of recombination systems. The papers are introduced by Professor J. R. Raper, and the concluding remarks on the genetical interest of incompatibility in fungi are given by Professor K. Mather. The heterogenic incompatibility of Podospora anserina, in which sexual interaction of different races is prevented by unlike alleles, is discussed by Professor $\mathbf{K}$. Esser, incompatibility in yeasts is described by Professor M. Ahmad, and the function of the mating-type locus in filamentous Ascomycetes by Dr. G. N. Bistis. A further eight papers are concerned largely or entirely with the multiple-allele incompatibility of the Hymenomycetes. Dr. P. J. Snider, in discussing incompatibility and nuclear migration, points out that existing techniques have not yet been fully exploited, and that the mechanisms of the movement of nuclei and its regulation are still quite obscure.

This publication provides a most useful survey of current knowledge and ideas in a subject of outstanding interest to geneticists. It is the more valuable because this symposium coincided with one on Genetic Recombination, which was unfortunate because, not only have most of the investigations of recombination been made with fungi, but the genetical study of incompatibility has led to the finding of novel mechanisms of recombination, notably Dr. A. H. Ellingboe and Professor J. R. Raper's discovery of specific factor transfer. These authors have shown that the mating-type factors in Schizophyllum commune may be specifically transferred from one strain to another, while other genes including a nutritional mutation situated between the two A factor loci are not transferred. Dr. Ellingboe, in his paper on somatic recombination in Basidiomycetes, suggests that episomes may be responsible for these transfers. Another contribution of outstanding interest in the present publication is Dr. S. Dick's repressional inhibition model of the action of the incompatibility factors in Schizophyllum and other Basidiomycetes with multiple-allele incompatibility. According to this hypothesis, the incompatibility loci are regulator genes controlling the production of specific repressor substances. In a monokaryon, the morphogenetic sequence leading to the formation of clamp-connections is repressed, but in a compatible dikaryon it is suggested that allelic differences in the 
repressor molecules cause them to unite with one another and so become inactive as repressors. The pathway leading to clamp-connections is thus freed. Dick's hypothesis that the incompatibility factors are regulator genes is of particular interest in view of Ellingboe's discovery of a novel recombination mechanism for these genes, because there is a possibility that the more familiar recombination mechanisms of crossing-over and conversion are specific to structural genes. It is evident that study of incompatibility in fungi, in addition to its intrinsic interest, may provide fundamental information about basic genetic phenomena. This book is invaluable for all who wish to keep abreast of the remarkable advances that have been made in recent years in knowledge of fungal incompatibility.

Dr. H. L. K. Whitehouse.

\section{PSYCHOGENETICS OF THE DOG}

GENETICS AND THE SOCIAL BEHAVIOUR OF THE DOG. J. P. Scott and J. L. Fuller. University of Chicago Press, Chicago, 1965. Pp. $468+$ xviii. $\$ 12.50$

For years, the small world of those of us actively involved in experimental psychogenetics-or behaviour genetics as the Americans seek to designate it - have been aware of an important progamme of research on the genetics of the dog going on at the Roscoe B. Jackson Memorial Laboratory at Bar Harbor in Maine. A series of reports on various aspects of the programme in the technical journals acquainted us with its admirable scope, and our appetites were whetted by some small packets of data specifically relating to behavioural inheritance which appeared from time to time. One such was seized upon by the present reviewers, re-analysed by the methods of biometrical genetics and published by them as early as I96I. Patience has been rewarded by the publication in this book of results gathered over the I 3-year period of this considerable research project.

Scott and Fuller decided to concentrate on five representative breeds of dog-the wire-haired fox-terrier, the American cocker-spaniel, the Shetland sheepdog, the beagle and the African basenji or barkless dog. Thus most of the major group of dogs recognised by breeders were covered, except for the toy and non-sporting breeds. In addition, a programme of crossings between two of the strains, the cocker-spaniel and the basenji, was attempted and this, while not complete in terms of all the usual possibilities within the $F_{1}, F_{2}$ and backcross pattern, accounted for 201 of the 470 experimental animals reared. In principle, the intention of the authors was to subject all this experimental population to a series of specially designed psychological tests in order to assess behavioural inheritance in the dogs, rearing them in a carefully controlled and standardised fashion. The realisation of this programme and the application of it to the three breeds not involved in the cross is described, together with interesting material on the evolution of the dog, and the development, both morphological and social, of all the breeds, provide much fascinating material. The reader interested in such matters will find rewarding reading in many of the chapters and, if he is a dog owner, both he and his dog may benefit from the understanding of dog behaviour which will almost certainly follow. He should, however, be warned that Scott's comprehensive system of classification of dog behaviour into nine broad categories of behaviour, useful though it may be at a descriptive level, is idiosyncratic, especially in relation to terminology such as 